\title{
Analyzing Social Factors Influencing Religious Beliefs of Learners
}

\author{
Hishyar Sardar Mustafa
}

\author{
Duhok, Kurdistan region of Iraq
}

\begin{abstract}
The purpose of this research is to examine the relationship between culture and religion on the other hand family and religion. A quantitative method used to analyses the present research. Multiple regression analysis used in this study, as seen in table (6), the coefficients analysis shows the B value for culture $=.884>0.01$, which supported the first research hypothesis which stated that there is a significant and positive relationship between culture and religious beliefs of learners, the $B$ value for family $=.884>0.01$, which supported the second research hypothesis which stated that there is a significant and positive relationship between family and religious beliefs of learners. However, the findings proved that the heights value was found to be for culture factor influencing religious beliefs of learners.

Keywords- Cultural factor, Social factor, Religious beliefs of learners.
\end{abstract}

\section{INTRODUCTION}

Religion means the style of life. Religion is a fact that has a considerable presence in life aspects and dimensions and it has woven in human's life. Human history started with divine direction and human being was never deprived from it. In each age, divine prophets announced God's message and the prophet, Muhammad, brought about the most complete religion for human beings and Islam became the religion of all humans and ages. Religion is a requirement originated from human nature. This need originates from inside of human being and it is required in direction of belief and faith and everybody requires this need. Individually human being feels secure and comfortable in light of belief in God and application of religious rules. This reality has been confirmed by psychologists. Religion is psychologically complex and includes a set of psychological categories such as emotions, beliefs, values, behaviors and environment. In another definition,

Religion is a subject that we encounter daily, because we follow a specific faith and the rules established by it. Religion is not only "researchable," but it is also of essential interest to clinicians, doctors, patients and health psychologists. Religion has the benefit of empowering the individual through connecting him/her to a community, and to a superior force, that might in turn give psychological stability. This ability to empower could be used by health workers to help those who struggle with a disease or to promote a healthier lifestyle. This empowering happens through consciousness of religious principles, such as the sanctity of human life, shared identity, meaningful roles in the community and society at large, a variety of spiritual, social and economic support, social networks, and even leadership for social change and protection in time of conflicts. The field of health sociology at large should move towards promoting culture as a means of understanding between health care providers and patients and in the interest of prevention, as well (Jamal \& Sharifuddin, 2015). Herbert Spenser believes that religion is confession of this reality that all creatures are imaginary forces that are beyond our science and knowledge. James - Prat believe that religion is recognition, emotion or behavior that is made based on perceived information or interaction with transcendent essence and it is assumed to play important role in human's affairs. Teachers, chaplains, religious and priests can also be good role models for young people. Sometimes if young people have a good experience of Religious Education in school their belief in God can be strengthened. R.E. class can open their minds and hearts to the mystery of God and how faith can be lived. In schools they can be exposed to meditation, liturgies, opening year masses, graduation ceremonies etc. which involve them in a meaningful way. This can provide a sense of union with one another and with God. It can encourage them to continue to pray, worship and to live by religious moral values in their daily lives. Seeing adults such as religious sisters and clergy who have a vocation to follow Christ, and who offer their lives in service of God and one another, can be a living example of the love of God in the world and the importance of religious faith. It reminds young people that 
religion has a valuable role to play in life (Jäckle \& Wenzelburger, 2015).

Religion is a response to divine call. Kant stated that religion is the rule governed on our entity and its dominance is originated from legislator and judgment. Generally, religion is a set of beliefs, feelings, acts, and experiences people face in loneliness and it is a divine thing. Religion enhances the relationship between social members and social requirements that help their unity because values that are fundamental in social requirement are common among religious groups. The aim of religious negotiations is not to create belief in God in human being rather the main aim is to pay attention deeply to God and religion and to create a deep religious insight in human societies. It seems that involvement of children in religious affairs can lead to social unity in future. Our society is a religious one and youths will be its actors in future. The present research aims to study socio-cultural factors affecting religious beliefs. For this purpose, the role of family, professors and teachers, peers, media, cultural activities (congregational pray and religious sessions, camping, trip and Eids) on religious beliefs is studied.

Apathy and indifference also influence religious beliefs and practices. In a fast-moving world of instant gratification, fast food, ready meals and instant broadband access to multimedia, the very notion of religious belief, prayer, reflection, becoming still and silent, is not always appealing. Teens can feel that God and religion don't matter anyway because there is so much more to stimulate them. The culture in which we live promotes a selfish type of philosophy - "me, me, me". There is little room for God and religious rituals in such an outlook. Adolescents are left feeling like all that matters are here and now, and that life is for enjoying and not to be bothered about spiritual matters or the afterlife.

\section{LITERATURE REVIEW}

\section{Family influencing religious beliefs of learners}

Why the scientific study of religion has a lot to gain from paying attention to the family is not difficult to explain. The family is the place where the intergenerational transmission of religious beliefs and practices takes place and thus is of crucial importance for the persistence and continuation of religious traditions and communities (Cohen \& Varnum, 2016).

Particularly, since success in the school milieu is valued by society and is seen as a principal determinant of adult success and independence, comprehending how parents socialize their children in the school setting promotes professional attention and research. In the literature, www.ijels.com nevertheless, only limited attention has been given to academic socialization as a recognized construct, and, if any, the research has encompassed how 5 certain parenting behaviors encourage favorable school experiences for children and how other styles of parenting hamper the academic success of the children. Strielkowski\&Čábelková, (2015) explained that academic socialization includes the assortment of parental beliefs and behaviors that contribute to children's school-as sociated development.

Religion, however, is communal, particular and defined by boundaries. It is spirituality incarnated at the social and cultural level. Religion takes the boundless and binds it into the limitations of language and culture, even as it may also transform culture. "Religion" derives from religio, "to bind back or to tie." Like "spirituality," the term "religion" has suffered from a multiplicity of definitions. The term "religion" is increasingly used by scholars in the narrow sense of institutionally based dogma, rituals and traditions. Kenneth Pargament (1997), defines religion broadly as "the search for significance in ways related to the sacred," encompassing both the personal and social, traditional and non-traditional forms of the religious search. Pargament uses the term, "spirituality" to describe what he calls the central function of religion that is, the search for the sacred. Although still relatively sparse, behavior genetic research has been conducted on religious involvement, and the current literature suggests three broad trends. First, religious affiliation appears to be transmitted primarily via social and cultural mechanisms (e.g., family-based socialization, normative pressures, memes, etc.), not genetic ones. That said, at least one study has reported a small genetic effect on being a member of a conservative religious, but the majority of the variation on this outcome was nonetheless shown to be the product of shared and nonshared environmental influences (Pereira-Salgado, et al. 2018).

Three observations underscore the importance of the family in this respect. First of all, in the Netherlands and other countries in Western-Europe inter-denominational switching and conversion later in life is rare. Most people stick to the denomination they were brought up in or they abandon faith altogether. This indicates that religious preferences, beliefs and affiliation are determined early in life as a result of parental influences. Secondly, although parents are not the only factor in this respect, they are by far the most influential.

Currently, a variety of interfamilial and extrafamilial influences is known to function in molding children's development. Mathras, et al. (2016) ecological model of development represents the interplay of these influences, stressing the significance of the relationships among

Page | 688 
settings, rather than a specific person or single setting. The significance of the dynamic interconnection of systems in shaping child development is likewise emphasized within the contextual systems model (Hoover, 2016), which focuses on children's academic functioning. According to this model, the child-family and school system act simultaneously to produce children's academic outcomes and overall school experiences. Understanding and augmenting relationships inside and between systems fosters children's school success.

Religious transmission may also occur in religious schools or in the religious community, but compared to the influence of parents, the influence of the religious school or the religious community is weak. Finally, religion is but one aspect of the value complexes parents may transmit to their children. Parents may for instance also transmit life style characteristics, sex roles, political party affiliation and general political orientation. However, parental influence is most noticeable in the field of religion. These observations clearly show that parents are crucial for the intergenerational transmission of religious beliefs and practices and thus for the persistence and continuation of religious traditions and communities. This makes the family a very important and interesting place for studying religion, as it is the most basic institutionalization of intergenerational relationships (Jiang, et al. 2015).

\section{Culture Influencing Religious Beliefs of Learners}

Culture can be defined as: "Behavior peculiar to Homo sapiens, together with material objects used as an integral part of this behavior. Thus, culture includes language, ideas, beliefs, customs, codes, institutions, tools, techniques, works of art, rituals, and ceremonies, among other elements." Beside individual differences between people, culture is the main driving force that separates humans into groups. Out of the many elements that define culture only two are readily observable: language and religion. Language is not only a means of communication; it also carries ideas, customs, and values. Religion may even be more influential for the human behavior. Many religious beliefs encompass rules for every aspect of daily life. For example, one finds rules on nutrition in nearly all world religions. Religious beliefs have also been highly influential in institution building. It is therefore only logical to conjecture that religious beliefs also impact economic exchange within and between religions. The questions that come to mind in this context are: Which religion is especially trade-promoting? Are there product groups for which religion has a more important role to play than for other product groups? Is there an influence when analyzing economic development? (Bell, 2017).
To establish (to the reader) the "cultural customs" as I witnessed and learned them from friends and contacts, I would like to talk about the idea that Hinduism is both a culture and a religion. This may seem obvious to many people, especially if they have lived in or visited. However, the concept needs emphas is since Hinduism forms a basis of a person's way of life, irrespective of his or her religion. If religion is a cultural tradition, is it possible to separate religion and culture? Can you belong to the Western culture and still practice Muslim religion? To this question must be added, can you be a white Christian in Africa without being labelled a colonist and oppressor? Can you be African without being labelled as primitive and prone to animism and magic? Has religion become a cultural identity marker in a South African context, demarcating the borders between people? Belonging to a particular religion implies belonging to a particular culture. From this position follows a crude generalization that to belong to a particular culture implies belonging to a particular religion. It is clear that religion and culture cannot be separated. However, maintains that Islam, for one, must not be viewed as a culture. The essence of Islam is religious. Many adherents of different religions will agree to this when applied to their own religious convictions. However, it cannot be denied that religion is a cultural expression. In this regard, culture and religion must be viewed as relatives. This has implications on how to study religion. If religion is seen as a segment of culture, studying religion becomes an anthropological and ethnographic exercise. The relation between culture and religion is an old and still on-going debate. Ever since Aristotle used the term ethnos to identify the groups of people living outside of the Greek polis, indicating them as primitive, people belonging to different cultures and religions could be labelled as 'outsiders, uncultured and irreligious'. During the Enlightenment period, Europeans took over this notion of Aristotle to label all non-Europeans as 'uncivilised'. The Enlightenment implication that all reality can be classified resulted in nations and people being hierarchically categorized. This classification was based on perceived natural mental physical and spiritual abilities (Dollahite, et al. 2018).

A cultural psychological perspective may offer some important insights for understanding how the influence of religion on secondary control and social affiliation may vary systematically by culture. For instance, people typically hold a more independent view of the self in more individualistic cultures, such as in North America. This view posits that the self is unique and separate from social surroundings and places a strong emphasis on personal choice and self-focused agency or control. On the other 
hand, people commonly hold a more interdependent view of the self in more collectivistic cultures, such as in East Asia. According to this view, the self is inherently connected to others, and value is placed on obligations and harmony in social relationships more than on personal agency (Chandler,2019).

Religious and cultural pluralism has been a prominent feature in human societies and this became intensified with the impact of modernity. The phenomenon of such pluralistic experience presents opportunities as well as challenges, particularly, for religious traditions and cultures today. H. Byron Earhart states in his foreword to E. Thomas Lawson"s book Religions of Africa (1985) that one of the most fascinating aspects of our history is the richness and varieties of its religious traditions. This has tremendous impact on human relations in view of the resurgence of religion and its growing role in both public and private life. The social and political processes of secularization, which were thought to supplant religion and its influence, have, in fact, served to strengthen it. In the age of globalization, religious traditions and pre-modern cultural forms, which used to be localized, have now become global phenomena (Fogiel,2017).

\section{METHODS}

The purpose of this research is to examine the relationship between culture and religion on the other hand family and religion. A quantitative method used to analyses the present research. The questionnaire consisted of two units, the first unit comprised of participants' demographic questions (respondent's age and respondents' gender. The second part of questionnaire consisted of 10 questions for culture affecting religious beliefs of learners, 10 questions for family affecting religious beliefs of learners and 10 questions about religious beliefs of learners. The sampling method used in this study was random sampling technique. The study was carried in education sectors in Duhok. The researcher distributed 90 questionnaires, only 71 questionnaires were received and being completed properly. The questionnaire is organized in multiple choice questions format. Five-point Likret scale used, the participants were asked to range from strongly disagree to strongly agree.

The researcher developed two research hypotheses to be measured in order to analyze relationship between culture and religion on the other hand family and religion.

Research hypothesis one: Culture as factor has a significant and positive relationship with religious beliefs of learners.

Research hypothesis two: Family as factor has a significant and positive relationship with religious beliefs of learners.

\section{RESULTS}

Table: 1 Background Information

\begin{tabular}{|l|l|c|c|}
\hline Description & Range & Frequency & Percentage \\
\hline \multirow{5}{*}{ Age } & $18-19$ & 15 & 21.1 \\
\cline { 2 - 4 } & $20-21$ & 20 & 28.2 \\
\cline { 2 - 4 } & $22-23$ & 20 & 28.2 \\
\cline { 2 - 4 } & $24-25$ & 14 & 19.7 \\
\cline { 2 - 4 } & 25 and more & 2 & 28 \\
\hline \multirow{3}{*}{ Gender } & Male & 64 & 90.1 \\
\cline { 2 - 4 } & Female & 7 & 9.9 \\
\hline
\end{tabular}

Table (1), shows learners demographic analysis contributed in this research. 15 learners were 18-19 years old, 20 learners were of 20-21 years old, 20 learners were 22-23 years old, 14 learners were 24-25 and only 2 learners were 25 years old and above. In terms of learner's gender; 64 learners were male and only seven learners were female.

Table: 2 Reliability Analysis

\begin{tabular}{|l|l|l|}
\hline Variables & Cronbach Alpha & Number of items \\
\hline Culture & .742 & 10 \\
\hline Family & .795 & 10 \\
\hline Religious beliefs of learners & .740 & 10 \\
\hline
\end{tabular}

Table (2), shows the reliability analysis for (culture and family) as independent variables and religious beliefs of learners as dependent variable. According to the reliability tests, the researcher found out culture's Cronbach Alpha = .742 for 10 items which are greater than .6 this means that culture's 10 items were reliable for this study, family's Cronbach Alpha $=.795$ for 10 
items which are greater than .6 this means that family's 10 items were reliable for this study, and religious beliefs of learners' Cronbach Alpha $=.740$ for 10 items which are greater than .6 this means that religious beliefs of learners' 10 items were reliable for this study.

Table 3: Correlation Analysis

\begin{tabular}{|l|l|c|c|}
\hline & & Culture & Family \\
\hline Religious beliefs of learners & Pearson correlation & $.933^{* *}$ & $.691^{* *}$ \\
& Sig (2-tailed & .000 & .000 \\
& $\mathrm{~N}$ & 71 & 71 \\
\hline
\end{tabular}

** Correlation is significant at level .05

As seen in table (3), the correlation between independent variables (culture and family) with religious beliefs of learners as dependent variable. The value $\mathrm{R}$ for the culture $=.933^{*} *$ which indicates that family is significantly and positively correlated with religious beliefs of learners and the value $\mathrm{R}$ for the family $=.691 * *$ which indicates that family is positively correlat ed with religious beliefs of learners.

Table 4: Model Summary

\begin{tabular}{|l|l|l|l|l|}
\hline Model & R & R Square & Adjusted R Square & Std Error of the Estimate \\
\hline 1 & .978 & .957 & .955 & .075 \\
\hline
\end{tabular}

As seen in the table (4), the value of $\mathrm{R}$ square $=.955$ which indicates that $95 \%$ of variables have been explained.

Table 5: ANOVA

\begin{tabular}{|l|l|l|l|l|l|}
\hline Model & Sum of Squares & $\mathrm{df}$ & Mean Square & F & Sig. \\
\hline Regression & 8.281 & 3 & 2.760 & 491.418 & .000 \\
Residual & .376 & 67 & .006 & & \\
Total & 8.657 & 70 & & & \\
\hline
\end{tabular}

a. Dependent variable: Religious beliefs of learners

b. Predictors (Constant), culture, family

As seen in table (5), the value of $\mathrm{F}$ for an independent variable and a dependent variable is $491.418>1$ which indicat es there is a significant as sociation between two independent variables and dependent variable.

Table 6: Coefficients

\begin{tabular}{|l|l|l|l|l|l|}
\hline \multirow{2}{*}{ Model } & \multicolumn{2}{l|}{$\begin{array}{l}\text { Unstandardized } \\
\text { coefficients }\end{array}$} & Standardized coefficients & S & \multirow{2}{*}{ Sig. } \\
\cline { 2 - 5 } & B & Std Error & Beta & & .737 \\
\hline (Constant) & .092 & .124 & & 26.568 & .000 \\
\hline Culture & .884 & .033 & .900 & 24.526 & .000 \\
\hline Family & .725 & .024 & .730 & \\
\hline
\end{tabular}

a. Dependent variable: Religious beliefs of learners

Multiple regression analysis used in this study, as seen in table (6), the coefficients analysis shows the B value for culture $=.884>$ 0.01, which supported the first research hypothesis which stated that there is a significant and positive relationship between culture and religious beliefs of learners, the B value for family $=.884>0.01$, which supported the second research hypothesis which stated that there is a significant and positive relationship between family and religious beliefs of learners. However, the findings proved that the heights value was found to be for culture factor influencing religious beliefs of learners.

\section{DISCUSSION}

It is certain that religious development is a subject that requires multiple, comprehensive, deeply psychological, and sociological assessments. When approached in the context of religious education, it seems possible to rank these processes which affect religious development as feeling of natural religion, feelings of affection and curiosity, need of faithfulness, religious awakening, religious socialization, and family. It is not possible to say that all of these processes on religious development are 
effective at the same time. The family that an individual is born into and differences, the social interactions, the talents, and possibilities as well as the education taken, social and cultural values have also considerable influence on this process. Moreover, one or more of the dimensions listed here can be the source of religious development for individuals. In this respect, it cannot be said that these processes which are the source of religious development affect the individuals with the same power and motivation. But it can be said that it draws a general framework. On the other hand, this diversity observed in the dimensions of religious development also reveals and nourishes the differences in individual religious experience. This situation leads to the development of religious life through inextricable and interwoven ties. From a developmental point of view, it should be emphasized that the development of belief is shaped first by parents and family, then by school and friend environment, after that by the individual's self-perception and internal experiences, and finally by religious institutions. In this sense, it is essential that the religion education should be given to the individual who is in every stage of the life by considering his/her developmental expectations, competencies, limitations, and other psychosocial elements. In the common life between the family and religion, the child's religious abilities can easily emerge. Religious awakening in childhood is largely dependent on the adult's interest, encouragement, support, and being model. If a child can first live in a peaceful spiritual environment in the family, a strong religious awakening can be seen in him/her. But, there may be different results depending on the content of the religious life in the family and family structure, the religious interest degree of the family members and the methods and habits followed for religious education. Religious behaviors, beliefs, and experiences are also part of the culture and they are regularly handed down from one generation to another. Culture and the environment shape the child's religious perspective as well as contributing to other developmental aspects and influence the awakening and development of religious belief. All observations agree that the influence of relatives is the most obvious factor in the formation of religious attitude. While the child learns to be a social individual, he/she also needs a model that he/she will imitate. Imitation skills also contribute to determining what the child will believe and how to behave in the future. However, the warm relationship that parents establish with the child is highly influential on him/her in taking their thoughts, behaviors, and beliefs as an example. Again, displaying the religious behaviors in the family is very important for the child to adopt them. Expecting the child to www.ijels.com behave in a way that the parents do not do is pedagogically meaningless, and this can cause certain doubts about the value of behaviors in the child's mind. There must be consistency among family members in religious matters as in other issues. Displaying a common attitude in the religious life by the parents who are considered as role models by the child is very important in terms of both gaining stability by the child in his/her religious life and eliminating the ambiguities that may arise in this issue. The family has a wide range of responsibilities for the child's education, upbringing, preparation for life, religiosity, religious experience, and behavior.

\section{CONCLUSIONS}

Belief education in the first years of life is largely the task of the family. It is important for a healthy belief development that parents develop positive feelings of trust, affection, and loyalty in this period and successfully transfer them to religious concepts. In terms of religious development, childhood is a dynamic period of time. Multiple regression analysis used in this study, as seen in table (6), the coefficients analysis shows the B value for culture $=.884>0.01$, which supported the first research hypothesis which stated that there is a significant and positive relationship between culture and religious beliefs of learners, the $\mathrm{B}$ value for family $=.884>0.01$, which supported the second research hypothesis which stated that there is a significant and positive relationship between family and religious beliefs of learners. However, the findings proved that the heights value was found to be for culture factor influencing religious beliefs of learners. For a healthy religious development, it is needed to create an environment in which qualified cognitive stimulants, rich language interactions, positive social-emotional experiences are presented to the child, and the child's independence is supported.

\section{REFERENCES}

[1] Bell, D. A. (2017). Against Individualism: A Confucian Rethinking of the Foundations of Morality, Politics, Family, and Religion by Henry Rosemont Jr. Philosophy East and West, 67(2), 565-568.

[2] Bhat, S. A., \& Shah, S. A. (2017). Religion and mental health: A co-relational study of family members of disappeared persons of Kashmir. Indian Journal of Positive Psychology, 8(3), 450-453.

[3] Chandler, M. (2019). Religion, Ritual, and Family. Philosophy East and West, 69(1), 20-29. 
[4] Cohen, A. B., \& Varnum, M. E. (2016). Beyond East vs. West: Social class, region, and religion as forms of culture. Current Opinion in Psychology, 8, 5-9.

[5] Dollahite, D. C., Marks, L. D., \& Dalton, H. (2018). Why religion helps and harms families: A conceptual model of a system of dualities at the nexus of faith and family life. Journal of Family Theory \& Review, 10(1), 219-241.

[6] Fogiel-Bijaoui, S. (2017). Transmitting the Nation: Family Individualization and Religion in Israel. Gender, Families and Transmission in the Contemporary Jewish Context, 90-101.

[7] Hoover, S. M. (2016). Rethinking Media, Religion, and Culture. Asian Communication Research, 13(2), 86-89.

[8] Jäckle, S., \&Wenzelburger, G. (2015). Religion, religiosity, and the attitudes toward homosexuality - A multilevel analysis of 79 countries. Journal of homosexuality, 62(2), 207-241.

[9] Jamal, A., \& Sharifuddin, J. (2015). Perceived value and perceived usefulness of halal labeling: The role of religion and culture. Journal of Business Research, 68(5), 933-941.

[10] Jiang, F., Jiang, Z., Kim, K. A., \& Zhang, M. (2015). Family-firm risk-taking: does religion matter?. Journal of Corporate Finance, 33, 260-278.

[11] Levin, I. (2016). Linking Religion and Family: Memories of Children Hidden in Belgian Convents during the Holocaust. In The Holocaust as Active Memory (pp. 27-40). Routledge.

[12] Mathras, D., Cohen, A. B., Mandel, N., \& Mick, D. G. (2016). The effects of religion on consumer behavior: A conceptual framework and research agenda. Journal of Consumer Psychology, 26(2), 298-311.

[13] Pereira-Salgado, A., Mader, P., \& Boyd, L. M. (2018). Advance care planning, culture and religion: an environmental scan of Australian-based online resources. Australian Health Review, 42(2), 152-163.

[14] Strielkowski, W., \&Č́belková, I. (2015). Religion, culture, and tax evasion: Evidence from the Czech Republic. Religions, 6(2), 657-669.

[15] Strielkowski, W., \&Č́belková, I. (2015). Religion, culture, and tax evasion: Evidence from the Czech Republic. Religions, 6(2), 657-669. 